\title{
How to Rise to Texts? On Joanna Pollakówna, an Essayist
}

There is a beautiful paradox in the fact that I was awarded for writing about painting; what does it mean to write about art if not a form of delight? So I was awarded for being delighted. What does it mean to analyse a painting if not a way of entering into it, its mysterious reality? So I was awarded for repeated attempts to get to know the reality created by humans longing for the supra-human dimension. What does it mean to follow processes which occur in art if not following the principles which govern the spiritual sphere? So I was awarded for looking for an order different than the order of temporary existence, which is typical of every man ${ }^{1}$

J. Pollakówna [a rough draft of a speech made probably on the occasion of receiving the prize of the Culture Fund]

1 J. Pollakówna, a rough draft, Adam Mickiewicz Museum of Literature in Warsaw. Pollakówna (1939-2002), poet, historian of art, author of three books of essays on painting: Myśląc o obrazach (Thinking about Paintings), Glina i światło (Clay and Light), and Weneckie tęsknoty (Venetian Longings), published between 1994 and 2003. A selection of her drafts titled Zapatrzenie. Myślac o obrazach, myśląc o malarzach (Reverie: Thinking about Paintings, Thinking about Painters) was published in 2012. She had written about art in an essayistic way much earlier, though. The tendency to go beyond the scientific description can be found in her $\mathrm{PhD}$ dissertation devoted to formists (Formiści, 1972), in Tytus Czyżewski (1972), or in Malarstwo polskie między wojnami (The Polish Painting between the Wars, 1982) as well as, or perhaps especially, in her texts on Józef Czapski, an artist particularly close to her (Czapski, 1993). Each of these books concerns different stages in the history of art and other stylistics: the drafts include works which, as it may seem, differ from one another more than they are similar (fervent presentations of mystical ecstasy by Francisco 


\section{Voir clair. The direction of beauty}

Joanna Pollakówna preceded the collection of essays from the 1994 volume Myślac o obrazach (Thinking about Paintings) with a quotation from Drugie Berga by Vladimir Nabokov: "What has been seen once may never come back to chaos". This choice is remarkably in accordance with the poetic idiom of the author of Dysonanse (Dissonances) highlighting the role of the sense which affects the shape of her writing the most ${ }^{2}$. But it is special for other reasons as well. It brings to mind the family context of Pollakówna's work, namely the works of her father, Seweryn Pollak, an essayist and translator, a connoisseur of Russian literature, who had died six years before the publication of the book ${ }^{3}$. It also brings to mind their correspondence containing vivid discussions on authors from behind the Eastern border, recommendations of new books, and reflections on language. Of the utmost importance for interpreting the motto can be the fact that in 1995 Pollakówna devoted her only poem about her own act of reading precisely to a novel by Nabokov.

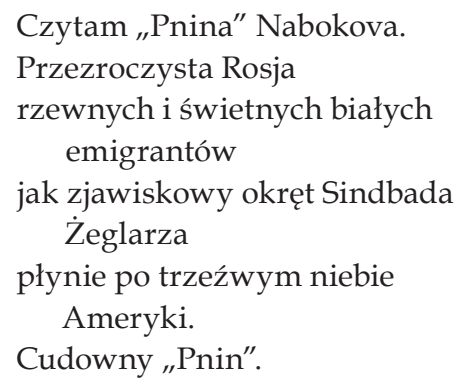

W przypływach pamięci nachodzących falami ostrego widzenia

Pnin widzi swoją utraconą Rosję Atlantydę zalaną nieszczęściem i krwią.
I am reading Nabokov's Pnin

Transparent Russia

of wistful and wonderful white emigrants

is sailing through America's sober sky

like the phenomenal ship of Sinbad the Sailor

Wonderful Pnin.

In the inflow of memory

Coming in tides of sharp vision

Pnin sees his lost Russia -

Atlantis soaked in misfortune and blood.

What a beautiful read.

Co za piękna lektura.

de Zurbarán and melancholic paintings by Artur Nacht-Samborski, crowded canvasses of Jacopo Bassano, and minimalistic experiments of Jacek Sempoliński). The principle determining Pollakówna's choice of these rather different works of art remains a secret. It is difficult, however, to deny that there is some secret code, since reflections on different authors are treated by the poet as an opportunity to save the same values: beauty and dignity of life. [Unless indicated otherwise, quotations and titles in English were translated from Polish]

2 "Each poem by Joanna Pollakówna (...) confirms the fact that she was a born poet, but each of her poems also proves that not only poetry was her domain, but also fine arts". J. Drzewucki, O tym, co widzialne i co niewidzialne (On What Is Visible and What Is Invisible), "Rzeczpospolita" 2003, no. 155, p. 20.

${ }^{3}$ Pollak highly valued the auto-translations of the author of Lolita, and in his theoretical works he made references to his views on translation, entering into polemics with them. Cf. S. Pollak, Granice swobód, "Twórczośćc" 1974, no. 4, p. 86. 
Jak wszystko na siebie zachodzi:

realność doświadczona,

realność zmyślona,

światy wyobraźni, roziskrzonej myśli,

światy bólu i śmierci - wszechludzkiej i swojej;

światy słowa - wznoszące

w powietrzu najściślej

zręby nieogarnionej, pospólnej

budowli.

Wielki smutek nad życiem

i zachwyt nad życiem.
How everything overlaps:

reality experienced,

reality invented,

worlds of imagination, of sparking

thought,

worlds of pain and death - univer-

sal and one's own;

worlds of words - erecting in the

air most accurately

frames of infinite common building.

Great sadness over life

And delight at life.

(While Reading)

(Przy lekturze)

133

The model of reception presented in the poem is interesting. First, because the person speaking comes across as someone extremely trustful towards the admired text: ready to follow it with her faith in the meaning, co-participating and co-feeling. Second, contrary to the logics of loss, her being lost in the book does not mean abandoning ' $\mathrm{I}$ ', but, rather, it enriches the uniqueness and separateness of her own reflection.

Traces of being carried away by the novel can be found in somewhat naive exclamations (without exclamation marks), closing the two descriptive stanzas ("Wonderful Pnin", "What a beautiful read"). They seem to be signals of helplessness in the face of an experience which is impossible to describe and which escapes attempts to reason it. This powerlessness can be associated with the condition of a layman blinded with unknown beauty, unable to react adequately when faced with miraculousness experienced so suddenly. This can be the nature of delight itself. It makes one aware of the mysterious perfection in the face of which one's own deficiency is highlighted. It restrains from complicating description formula. It urges one to return to primary notions - not yielding to any transformations and reductions - notions which are made obvious by illumination itself, even if they had been questioned before (for reasons which one still remembers), such as truth, good, and beauty ${ }^{4}$.

Drawing attention to the escape from the last of these categories (and preferring loftiness) in critical and literary discourse, Marek Zaleski ponders on the non-compatibility of the contemporary language of description,

${ }_{4}$ Voir clair dans le ravissement (or, to be precise, voir plus clair...), a phrase from Swann's Way by Marcel Proust, recalled by Jan Błoński in the title of his essay on the works of the French artist, seems to confirm that delight enables one to achieve a special standpoint, a clarity of vision. A wider context of the quoted slogan shows that a 'clear' vision of the reality is the opposite of concentrating on fleeting sensations and 'opaque words'. Cf. M. Proust, Du côté de chez Swann, Paris 1946, pp. 210-211; J. Błoński, Widzieć jasno w zachwyceniu: szkic literacki o twórczości Prousta, Warszawa 1965. 
shaped through "avant-garde experiments" and "intellectual provocations" with authentic experiences of reception ${ }^{5}$.

Why am I reading aloud an old poem by Mickiewicz and I know it is beautiful? Why am I reading a new poem by Eugeniusz Tkaczyszyn-Dycki and I know that this poem is beautiful? Why, though, when talking about this poem am I beginning to speak a language which deceives the voice, and why do I know that my voice deceives my thoughts? (...). Delight is no longer enough, it is more interesting to investigate the reasons for our delight ${ }^{6}$.

Zaleski's observation, surprisingly true in relation to some interpretation practices, was evoked with an antithetic intention as it does not have much in common with the essay-writing discussed here. Pollakówna, a historian with an impressive workshop, a connoisseur of painting, is drawn to works of art not through the willingness to participate in the intellectual game or catalogue meanings, but because of the need to rise to the mystery, the need to answer the call of beauty. "I do not understand" and "I do not comprehend" - as strategies of being towards paintings - do not only open, but also close many of her essays.

"This abundance of the 17th-century Dutch painting! The reasons for such a magnitude of talents at different times and places of Europe are beyond comprehension (...)", as the poet begins her essay Światto i miara (Light and Measure) ${ }^{7}$. She ends Alchemia światła (Light Alchemy) with words: "And we will remain like that: illuminated and anxious when the power of the painter's call through time takes our wistful delight somewhere beyond the painting into some non-localised region which is hardly possible to be sensed" (p. 149). Fascination with the work of art remains both obvious (in the certainty of feeling, a spontaneous act of giving beauty the reason for existence) and incomprehensible (as it makes one aware of the imperfection of notion categories imposed by the human kind). This paradoxical bi-direction of art reception (clear, but incomprehensible) brings to mind mystical experiences.

"(...) Rapture leaves behind also a certain strange detachment, which I shall never be able to describe" (p. 177) are the words of Saint Teresa of Ávila as quoted by Pollakówna. This experience for the mystic (she also referred to it as "ecstasy") is a sign of being carried away by God ("The Beloved suddenly gathers the soul up (...) The divine cloud ascends to heaven, taking the soul along with it, and begins to reveal to her the heavenly wonders God has prepared for her"8). In the writing of Saint Teresa, the experience of delight is independent from a human being's will: this is a divine secret to which one may respond only with meek acceptance. Ecstasy embraces

${ }^{5}$ M. Zaleski, Stowo zapomniane?, [in:] Dwutygodnik.com. Strona kultury, https://www.dwutygodnik.com/artykul/360-slowo-zapomniane.html, [accessed 1.08.2019].

6 Ibid.

7 J. Pollakówna, Zapatrzenie, [in:] Zapatrzenie. Myśląc o obrazach, myśląc o malarzach, Gdańsk 2012, p. 180. The subsequent quotations from Pollakówna's essays, unless it is indicated otherwise, are quoted from this edition, with the page number in brackets.

8 Teresa of Ávila, Księga życia, transl. H. Kossowski, Kraków 2014, p. 269. 
both the soul and the body. The significance of dealing with the Absolute and supernatural phenomena which accompany it causes fear: "And further, I confess that it threw me into great fear, very great indeed at first; for when I saw my body thus lifted up from the earth, how could I help it? Though the spirit draws it upwards after itself, and that with great sweetness, if unresisted, the senses are not lost; at least, I was so much myself as to be able to see that I was being lifted up"

Pollakówna recognises the mystical dimension of delight, which is like an outburst of spiritual reality into the human world. Fascination with the painting (including, like mystical ecstasy, agreement to her own deficiency, to "I do not know where from" and "I do not know why") brings the poet to transcendental regions, inaccessible to knowledge and senses - towards presentiment, but also, perhaps, towards the desire of truth contained in beauty ${ }^{10}$.

Coming back to the poem Przy lekturze, what delights Pollakówna in the novel by Nabokov is the property of each work of art which leads to (spiritual) synthesis in accordance with Baumgarten's aesthetics that is so close to her. It is difficult to resist the impression that reading is already preceded by the desire of the pervasive sense enabling one to feel it ("As everything overlaps"). Pnin (but also the mystery of any other text or painting seen 'clearly in delight') triggers a special potential of the subject experiencing delight: readiness to go beyond the reaction of the senses, awaken the intuition of the principle governing the world.

This perspective allows one to look for inspiration with modern aesthetics in the situation of reading which was evoked in the poem, with the moment of its birth or even the prenatal moment for its constitution.

The notion aisthesis was originally used at the turn of the 17th and 18th century - still before Baumgarten's Aesthetica was written - in theological debates among pietists in Halle. The topic of those discussions was the problem of communication between God and human beings or, to be more precise, the way in which God passes the revealed truth to humans and the role human senses play in this process.

[August Hermann] Francke (...) considered the category of aisthesis with regard to the exergies of the Biblical text. One of the methods of reading it was to grasp it considering its analogia fidei, i.e. reading it as a certain closed narrative, a stylistic whole, as an order which the author wanted

9 Ibid.

${ }^{10}$ Describing the painting titled Joseph the Carpenter by Georges de La Tour, Pollakówna notices "peculiar ambiguity, simultaneousness of worldly and eternal existence, physical and spiritual". J. Pollakówna, Święty Józef Cieśla (Joseph the Carpenter), [in:] id., Myśląc o obrazach, Warszawa 1994, p. 25. 
to convey, and at the same time accounting for its affective side, i.e. the spiritual condition of the author, which is manifested in the given order ${ }^{11}$.

The synthetizing tendency, understood as looking for a code in a work of art that enables one to understand the world's mysteries, is manifested not only in the presented poem by Pollakówna, but also in her essay-writing. Aisthesis is connected with the aforementioned trope as it points to the fact that the sense of beauty calls for a reaction. "How can we pay off the debt of delight to paintings which attract our attention?", the poet asks on the back cover of the volume Myślac o obrazach ${ }^{12}$. A similar question appears in the poem Wieczność (Eternity): "How to rise to the texts inaccessible to the worlds?"13.

Nabokov's novel performs a mediating function in Pollakówna's work. It has an uncertain status. It is something more than just a pretext (for a poetic answer), yet something less than its destination. The creative reception of the text caused by its uniqueness is finally directed at itself and looking for general truths, already detached from Pnin and his lost Russia. This interpretational excess (not being, however, an over-interpretation) seems to be an effect of the feeling of beauty making the subject to situate towards the work of art.

Certain doubts are raised with regard to the unique kind of contact with the text and image motivated, on the one hand, by careful perusal, pursuing of the sense, and the state of the pre-understanding ("pre-feeling") of looking and experiencing ' $\mathrm{I}$ ' on the other. Does the creative surplus in the reception, a tendency to rise above the art object itself, still fit in the scope of the interpreter's competences ${ }^{14}$ ? Perhaps this question should be asked in a different way: is it only such an interpretation filtered through poetic sensitivity that stands a chance of truly getting closer to the work?

11 P. Kozak, Estetyka A. G. Baumgartena jako pietystyczna lektura filozofii C. Wolffa - draft, https://www.academia.edu/10784122/Estetyka_A.G.Baumgartena_jako_pietystyczna_lektura_filozofii_C.Wolffa, [accessed 10.08.2019]. Kozak, rehabilitating the author of Aesthetica, argues that: "Baumgarten was convinced that sensual knowledge exceeds the boundaries of scientific cognition and approaches the cognition of metaphysical material truth (...)".

12 J. Pollakówna. Myśląc o obrazach, p. 19. The same words - about the debt that needs to be paid off, the debt incurred to beauty - are used by Błoński in his introduction to an essay on Proust. Cf. J. Błoński, op. cit., p. 5.

${ }^{13}$ J. Pollakówna, Wieczność, [in:] id., Wiersze zebrane, op. cit., p. 441.

14 This question touches upon problems undertaken in the field of, for instance, the theory of literature over the last few decades, summarised in the question: what content extracted during the perusal is on the part of the work and what content is on the part of the recipient? Reflections on this topic, including issues centred around literary communication, have been undertaken by researchers representing different methodological schools and are alive till now. It is worth mentioning here, for instance, Mikhail Bakhtin and Jean-Paul Sartre as well as, in Poland, Edward Balcerzan, Michał Głowiński, Aleksandra Okopień-Sławińska, and Janusz Sławiński. Looking for a formula for a non-empirical transmission instance, Umberto Eco proposed the concept of the Model Author, being, firstly, the subject shaping the author's image in the text and, secondly, a hypothesis constructed by the reader. Cf. U. Eco, Autor jako hipoteza interpretacyjna, [in:] Lector in fabula. Wspótdziałanie w interpretacji tekstów narracyjnych, transl. P. Salwa, Warszawa 1994, pp. 90-96. 
For Pollakówna, the reaction to "I do not know" caused by illumination consists in using her imagination, which is the only one capable of withstanding the mystery of beauty. It seems that crossing boldly the borders of "interpreting" towards "adding" represents the greatest value of her essay-writing. In his review of Weneckie tęsknoty, Przemysław Trzeciak notices that:

Joanna Pollakówna was the closest to the truth of the painting in those situations when she subdued her workshop of the art historian and launched her poetic imagination, since the only language capable of saying something true about the painting is the language of poetic synthesis and condensation. Paul Ricoeur granted poetry the authenticity of higher order, since it is capable of uncovering paradoxes which represent an essential aspect of truth. Art may be expressed only through art or silence saturated with emotion so strong that it becomes inarticulate ${ }^{15}$.

Georges Didi-Huberman explains that capturing the visible should be replaced by "capturing through the visible". Hence, the reaction to the impact of the painting may not be an attempt to describe it or to catalogue the senses. Contact with a work of art requires involvement in the process of "producing and transforming" on the part of the recipient:

(...) the efficacy of these images is not due solely to the transmission of knowledge-visible, legible or invisible-but that, on the contrary, their efficacy operates constantly on the intertwinings, even the imbroglio, of the transmitted and dismantled knowledge, of produced and transferred not-knowledges. It requires, then, a gaze that would not draw close only to discern and recognize (...). Something like a suspended attention, a prolonged suspension of the moment of reaching conclusions, where interpretation would have time to deploy itself in several dimensions, between the grasped visible and the lived ordeal of a relinquishment. There would also be, in this alternative, a dialectical moment (...) consisting of not-grasping the image, of letting oneself be grasped by it instead: thus of letting go of one's knowledge about $i t^{16}$.

Thus, the way in which the poet describes the work of art goes beyond the level of interpretation. From illumination on "letting go of one's knowledge", or even making it naive ("Wonderful Pnin!"), through in-depth and creative reaction which leads the author in the direction of spiritual precognition.

${ }^{15}$ P. Trzeciak, Barwy Wenecji, “Nowe Książki” 2003, no. 7/8, p. 11, translation mine. In a similar way, the works of the author of Glina $i$ światło are assessed by Marek Zagańczyk: "Pollakówna's essays go beyond descriptions of a work of art. They are an attempt at extracting meanings, discovering the essence of the admired work. Nonetheless, Pollakówna does not write directly what is concealed behind the matter of the canvas. She knows that words tend to destroy the fragile construction". M. Zagańczyk, Rozmyślania o obrazach, "Zeszyty Literackie" 1994, no. 47, p. 129.

16 G. Didi-Huberman, Przed obrazem. Pytanie o cele historii sztuki, transl. B. Brzezicka, Gdańsk 2011, p. 16. 
Przy lekturze, a poem seemingly distant from the issues important in Pollakówna's essay-writing, speaks volumes about the model of the reception of art that is characteristic of the poet. The relation between the painting and the admirer, which becomes asymmetrical in Pollakówna's essays, is indeed, as the poet writes, a kind of "reverie", half-prayer contemplation, conducted in humbleness, in accordance with the ars longa, vita brevis principle, and indeed it contains a magnitude of space for personal, poetic response, and as such is a sign of 'being captured' by the work of art. It is due to this acceptance of being carried away by the painting that the contact with beauty may be reminiscent of a mystical experience. The reception of art is supposed to be - in accordance with the motto from Drugie Berga - the remedy for the chaos of the world, liberation from the prevailing chaos. It is also supposed to be an attempt at the spiritual experiencing of "everything" - "clear ecstatic seeing of the whole"17.

\section{Closer to the essay: Making the present}

Poetry-inspired recognitions concerning the reception of art by Pollakówna (and longings being part of this reception) should be confirmed by reading her essays. It is worth stressing here, however, that the two areas of the author's literary output are fundamentally inseparable. Her poetry and prose are very close to one another in imaging, metaphors, and directions of artistic search. Some essays or poems by Pollakówna seem to rhyme. The same desires can be heard in them and they raise similar questions: about the boundaries of cognition and ways of experiencing the world. One should not, therefore, make references to her drafts on painting, while at the same time forgetting about her poems, or reference poetry without considering the context of her essayistic works.

In Spizarnia mistyczna (The Mystical Larder), one of the most interesting texts from the volume Myślac o obrazach, the author ponders on the uniqueness of still lifes by Sánchez Cotán, a 16th-century monk and painter. The point of departure for the reflection is the aforementioned "loss of knowledge" that results from experiencing beauty. Pollakówna confesses to disorientation, being aware that without experiencing uncertainty each answer is always vague and hasty. She expects the unexpected in a work of art; she looks for what is concealed in what is visible, available to the eyes and senses. Preparing for the unknown requires verification of the tools of cognition. Reason and experience merely suggest the correct path.

Bodegones (...) are neatly ordered larders (...); brightly lit baskets of fruit placed on cornices against a dark background and flowers, vases or

17 J. Pollakówna, Spiżarnia mistyczna, [in:] id., Myśląc o obrazach, p. 19, translation mine. The simultaneousness of experiencing delight and loss (of knowledge) is also striking in the essay on the works of one of the most outstanding Kapists, also known as Colourists: "It is the surprising fullness of painting by Nacht-Samborski that makes it so difficult to grasp. Even if sometimes reflexes of artistic trends of contemporary times are visible in this rich substance, they are reprocessed, alloyed in a specific and unique way" (p. 325). 
cakes appearing out of nowhere. These specific and beautiful images of smoothened things spoke only about themselves. The background was dark, the objects existed just for their own sake and light was supposed to reveal their splendour. Why do we suspect that there is something more to Cotán's floreros and bodegones, why do we get entangled in futile speculation, gazing, involved in the puzzle, wishing to understand something from the mystical experience which, as we guess, was their creative element? ${ }^{18}$

The poet involves readers in the illumination with the work: it is their vision that makes her suddenly choose the plural form. Those who she perhaps would like to see with her in the museum in Granada, in front of Cardoon and Carrots, faced with a mystery together with the author, feeling the same way. They are equally surprised by the secret code encrypted in floreros and bodegones, ready to agree with Pollakówna and also with Herbert, who expressed their common intuition in a very accurate way: "Our task is not so much to solve riddles as to become aware of them, lower our heads before them and prepare our eyes for constant rapture and surprise"19.

An attempt at getting closer to the work of art does not take place without an attempt at getting closer to humanity; this concerns not only the collectivity of reception but, most of all, the need of contact with the creator. The thought about the author precedes considerations about the artistic message itself. Draft portraits of painters can be nearly always found at the beginning of Pollakówna's essays. The author also begins Spiżarnia mistyczna with presenting Cotán.

The Baroque painter, the author of Still Life with Quince, Cabbage, Melon and Cucumber, had lived in Toledo for the first forty years of his life before he entered the monastery in El Paular. It is precisely that Spanish town - a place where Academia de Matemáticas was founded in 1582, St. Theresa set up the Convent of the Carmelites, and El Greco created The Burial of the Count of Orgaz - that becomes the most important source of knowledge on Cotán for Pollakówna. This is a special knowledge - specialist, carefully selected, regained from hardly accessible archives, but necessary to such an extent to which it is possible to hook the nets of imagination in it. The poet suggests a relationship between the painter's outstanding, unobvious skills (he was capable of repairing hydraulic devices and monastery clocks) and the spiritual and mental climate of the 16th-century Toledo, a town of "astronomy, mathematics, geometry, and religion"20.

Cotán is portrayed with the use of just a few lines: in a nutshell, metaphor, detail. Pollakówna is not interested in ordering biographies or collecting dates or names. She is capable of looking with affection at the property inventory made by the artist, "a work on music with no title", only to draft a wide perspective of the atmosphere of the whole epoch soon after. There is ample space for speculation for both the readers and the author between the

18 J. Pollakówna, Spiżarnia mistyczna, p. 18.

19 Z. Herbert, Martwa natura $z$ wędzidtem, "Fundacja Zeszytów Literackich", Warszawa 2003, p. 137.

${ }^{20}$ J. Pollakówna, Spiżarnia mistyczna, pp. 18-20. 
detail, the remnant, and the broadly sketched background. It is possibly this place that gives rise to their spiritual liaison, the specific "emphatic pact"21.

It seems that the frugality of 'informing about', the reluctance to notify that is typical of Pollakówna, is an expression of respect for the uniqueness of a human being and the uniqueness of a work of art. As it is impossible to say everything (and because the perspective of "everything" will be different for each person), it is rather appropriate to suggest, put into consideration. Hence the poet uses the vast knowledge and detailed notes in a critical and fastidious manner: in her essay on Francesco Guardi, she quotes the testament of one of the clients of his studio, while writing about Jean Baptiste Chardin, she pays attention to the property inventory of the artist's first wife.

Several comments concerning Pollakówna's approach to the topic of biography may be found in her essay titled Malarstwo $i$ życie (Painting and Life), devoted to Józef Czapski. The poet expresses her conviction about the internal integrity of the artist: "Biographical facts are not to be skipped when one analyses the painting of a man who constantly smelts his life and impulses from life into the precious ore of consciousness. The vividness of experiencing the world on the religious, emotional, intellectual, and aesthetic levels is pulsating in Czapski with an unwaning intensity" (p. 261).

The factual detail is not sufficient in collecting knowledge (collecting entails greed, constant insatiability threatening with getting stuck in obviousness), yet it is sufficient for imagination. And it is imagination used where scientific methods reveal their whole impotence of objectivism that is capable of making an author and a work of art present.

The essay on Tytus Czyżewski begins like a short story:

One May evening of 1903 a short, slightly disabled young man, a student of Cracow Academy of Fine Arts, having seen a performance on Bolesław II the Generous in the Cracow Municipal Theatre, sat down on a bench with a friend of his in the Planty Park at night and spent the short spring night engaged in a conversation until dawn, full of delight, overwhelmed by the play they saw. (p. 224)

This is a snapshot, one frame from a film: still unknown characters captured in a moment which we see through the eyes of the narrator. In her attempt to get closer to authors, Pollakówna uses strategies developed on the ground

${ }^{21}$ It is possible to sense both sensitivity and imagination in the silhouettes of painters drafted by the poet. Also the tone of humour mixed with affection can be heard here. We may read in Ufność tragiczna that: "Having acquired great artistry in painting animals, Jacopo Dal Ponte, a painter of Bassano, decided to paint a picture in which his skill practised many years would shine the most. That won him popularity which was slightly ambiguous as theoreticians of the 16th and 17th century painting sneered at such low topics as animals and objects, and the abundance of shining copper crockery, gaudy foul and fluffy game in Biblical scenes painted by Jacopo offended their sense of taste. This kind of religious vision full of love for the details of the visible world did not ensure the painter with too many orders for Venice churches and public buildings for many years" (p. 150). 
of poetry: she saves the moment, suspends the principle of verifiability 22 . The poet introduces readers into the works of the author of Akt $z$ kotem (The Act with a Cat) not with a list of his merits, a critical commentary, but with a picture of a man excited with the issues of art, involved in the discussion which continues till the clear dawn in May. Czyżewski - alive and possible to be seen - is most important to her.

Pollakówna's characters, fished from the depths of history, saved from pale characteristics in lexicons and encyclopaedias, become tangible for a moment. The fragments collected by the author clearly include also these that remain a poetic speculation. This speculation based on thorough studies is not difficult to believe, though ${ }^{23}$.

The concentration on the moment as a method of the poetic making-present also refers to the transition from the person to the work. As this space between the subject and the very effect of their work is also vital for the author: what does the painting workshop look like? How are alchemic recipes for hues and shades made? Is the artist's domain to accomplish the subsequent stages of the work meticulously and precisely, or is it just madness, anxiety, and following the inspiration?

Pondering on two almost identical versions of still lifes by Jean Baptiste Chardin, an 18th century master of genre scenes, the poet writes:

It is poignant to think how the painter, painting a replica, slightly moved the objects; one may imagine the hand which slightly draws the trough handle to himself millimetre by millimetre, pushes the white root of the leek somewhat outside the edge. These are careful, affectionate movements. And they are instantly followed by a flush of infinite concentration, remembered in the ways of co-existence of those several shapes which are round, flat and oval, in the mutual penetration of their colours (p. 193).

Revealing the moment of painting the picture happening in the 'now' of the reader requires that Pollakówna should find herself in the 'then' of the painter. Experiments with time and trips of imagination connected with it

${ }^{22}$ The thought about capturing the moment (in a possibly large frame, preserving the multitude of colours, meanings, contexts) as opposed to the impossibility of saving the whole time (as abstract, inaccessible to the senses) stands out both in Pollakówna's essays and in her poetry. In one of her poems, the poet writes: "Nie umykaj z tej chwili/, z jej bladego lśnienia/ bo popadniesz w bezdomną/ wieczność przeoczenia" ("Do not flee from this moment/, from its pale shining/ as you will fall into homeless/ eternity of negligence"). In her essay on Jean Baptiste Chardin, the poet preserves what is possible to see in one moment: "When Jean Baptiste Simeon Chardin painted his three small pictures depicting kitchen utensils approximately in 1734, he was thirty-five years old. Ten years before that he obtained his master title in the Académie de Saint-Luc and married sickly and poor Margueritte Saintard. Soon after, in 1728, he was admitted to the Académie Royale de Peinture et de Sculpture and renounced his previous much less honorable title" (p. 192).

${ }^{23}$ The apocrypha in the essay on Pierro della Francesca save the human kind: "There is no trace left after the frescos painted allegedly by both masters [Pierro della Francesca and Domenico Veneziano - a note by ASW] in Sant Edigio. We can imagine that twenty-something Pierro della Francesca looked at powerful and delirious frescos by Uccello painted nine years earlier in the galleries of Chiostro Verde near Santa Maria Novella (...). Next to them, in a church, a work which he could not have been indifferent to: majestic Holy Trinity by Masacci (...)" (p. 8). 
mean withholding the principles governing the world. The meeting of the painter and the recipient, of the poet and the reader, which is an inherent part of the contact with art, questions the temporary order, challenges the obviousness of transiency, which is, in fact, the principle of detachment ${ }^{24}$. The community of delight reveals new ways of time existence.

In the same essay on Chardin, Pollakówna asks (and responds):

Does the human spirit know only one way of approaching another dimension (...)? The most urgent gaze, to the point of getting lost, of melting with the visible. With the one being created. This intensified concentration establishes its own time, beyond the roundness of human notions of the past and future. It knows only the present and drowns these several suddenly sanctified shapes in it, like in amber, like in a clotted lump of light. The thick paste of the paint transports through years that inviolable, triumphant and meek delight ${ }^{25}$.

A part of Pollakówna's essayistic work consists in the poetic making-present of painters and moments of creation, a special work of imagination, sometimes inclined to micro-observation ('micro-inspiration'), sometimes with panache abolishing the limitations of time and the detachment of history.

Standing in front of the painting, where she was brought by a presentiment of "superhuman dimension", the author looks for traces of "something more". She peers into the canvass. She looks, tastes, touches, listens. "What does considering the painting involve if it is not a way of entering the picture, its mysterious reality?" The way in which this "entry" is made brings to mind illumination: it is unique and intimate, experienced in a flash of ingenious thought, in accumulation of impressions entangling with one another. Some ekphrases seem to be clairvoyance: they capture impressions which are available to only this one chosen person trying to keep in contact with the Unnamed on behalf of the readers. The boundaries of heresy are tested here, it is examined what a human being is still allowed to do and what is concealed from them.

The notes of the poet from art galleries preserve her first responses to paintings: her attempts to stop the escaping feeling. Pollakówna's sketchpads are unique 'documents of seeing', registering in hasty uneven writing the toil of keeping pace with the reaction - of the senses? Intuition? Imagination? "The sky full of clouds churning with pastel foam, fleeting shapes, blown through, trembling (...)" - we read on Healing of Tobias by Antonio

${ }^{24}$ In Głód nieśmiertelności (The Hunger of Immortality), her last essay, Pollakówna watches Renaissance portraits being an expression of faith in the possibility of suspending transiency rules. The context of the near end of her life gives these considerations a particular heroic dimension: "Rebirth is the time when human beings entrusted themselves to memory. Memory was supposed to save the fleeting human existence which gained the highest value when we were expecting to revive the glory of the ancient. It was the time when the nameless mass suddenly scattered into a community of individual people, from which each in their separateness born once for eternity was worthy of and desired prolongation of their fate beyond the boundary of death, some projection into the future" (p. 159).

25 J. Pollakówna, Myśląc o obrazach, p. 11. 
Guardi from the Venice church San Raffaele Arcangelo - "avian featherness, the giddiness of Angels spreads to people, their trembling silhouettes"26.

Also in Venice in the Church of Madonna dell'Orto, Pollakówna's attention is drawn to Presentation in the Temple by Tintoretto. Her handwriting, normally fine and neat, becomes difficult to read as she describes the painting in a few sentences. Some words are replaced by abbreviations. It is worth paying attention to poetic inversions which make the note similar to a record of mystical illumination: "Tawny light, powerful half-turned figure of a woman leading a girl onto stairs. On the 1 . an old man in agitation of robes pale golden. Everything ascends on huge stairs turning upwards and left into the overcast sky and [illegible] illuminated"27.

Only small changes are introduced between notes and essays: sentences are subjected to grammatical discipline, they are linked to theoretical and historical comments. Editing the notes does not order, however, the signals which are synesthetic from the beginning, permeating each other, received by different senses at once. Different senses at the same time. The simultaneousness of experiencing textures, hues, shapes, and sounds results in the condensation of the description, its synthetisation. The text which is created is a pure essence, an extract from experiencing the work of $\operatorname{art}^{28}$.

"It is possible to hear (...) the painting sonority of this ascetic and intricate composition in colour", as Pollakówna writes on Still Life by Cotán. It would seem that the overwhelming power of the (multi)sensual, immediate sensation of the painting would move considerations on its content into the background. But it is not so. Savouring the work of art is unhasty and precise. The poet is capable of subjecting her impression to careful critical analysis. "The painting sonority" of Still Life by Cotán is confirmed by the thorough summary of the performance: "the cool yellow of the quince; the greens of its leaves and the cabbage, tart and only slightly warmed with yellow light. Another green, lighter, on the skin of the melon, is intensified by darker stripes and the place of the cut is highlighted by concentrated green hue only to turn brightly into pale salmon pink of the revealed pulp with palpably painted seeds" 29 .

The author reveals the content of the painting filtered through her poetic sensitivity which does not become obvious through this revelation: conversely, its spiritual, still inaccessible content becomes even more manifested. The unnamable remains unnamable. At the same time, though, the assiduity of the feeling, the curiosity of the imagination, and the senses are rewarded: "an order different than the order of temporary existence" emerges against the background of the reflections - the presentiment of "the spiritual whole", which is borrowed (for good) from the painter, becomes the gain of the interpretation.

${ }^{26}$ J. Pollakówna's private archive. The materials were made available by courtesy of Wiktor Dłuski.

${ }^{27}$ Ibid.

${ }^{28}$ The word "extract" is also used by Pollakówna in the title of an essay on the painting of Nicolas de Staël. Cf. J. Pollakówna, Ekstrakt widzialnego (The Extract of the Visible), [in:] Myślac o obrazach, p. 119.

29 J. Pollakówna, Spiżarnia mistyczna, pp. 16-17. 
Comparing (...) the still lifes by Cotán we are beginning to imagine how the purification of his seeing thought gradually progressed. How the idea of super-order began to shine through things, embracing, like almighty music with its gaps of silence, all that was created.

Cardoon and Carrots as well as Quince, Cabbage, Melon and Cucumber seem to be the records of the illumination, clear ecstatic vision of the whole (...). The reflection itself comes to life in them which goes far outside its porch: word or sparse picture. It contains second sight of more general harmony, extended into a mystery ${ }^{30}$.

\section{Reading essays of the poet: The directions of perception}

A lot has been written on where to look for the point of departure for Pollakówna's essay writing. Attention was paid to the spiritual, meditative dimension of her contact with the work, to the particular emphatic attitude to artists among whom she chose "broken, not fully fulfilled who did not find in themselves the classical composure of Rafael"31. In her valuable synthetic draft titled 'Rozmyślające widzenie'. Projekt eseistyczny Joanny Pollakówny ('Meditating vision' Joanna Pollakówna's Essayistic Project), Dobrawa Lisak-Gębala notices that the author of Glina i światło "made works of art her «escape from reality» enabling her to speak indirectly about other fundamental topics and provoking indirect manifestation of her own thoughts and feelings" ${ }^{\prime \prime 2}$. The researcher notices that "(...) Pollakówna's writing realised the path of essayistic reflections described by Lukács, leading from the concrete object (...) to «ultimate issues of life» to answers to the question: «What is life, a human being, fate?»" 33 .

It is worth adding that these answers are always attempts of hope. Trying to find in painting the truth on immortal art, Pollakówna tames the truth

30 Ibid.

31 D. Mazur, Eseje Joanny Pollakówny o malarstwie - otwarcie na doświadczenie mistyczne, [in:] Strony Joanny Pollakówny, eds. A. Kozłowska, J. Zieliński, Warszawa 2016, pp. 295-310; A. Arno, Gęstość słowa, "Zeszyty Literackie" 2014, no. 4, p. 216. The author of Weneckie tęsknoty left surprisingly many comments on the tasks to be fulfilled by her own essays and reasons for reflecting on art (surprisingly many as opposed to the few auto-comments concerning her poetic output). She writes in Zapatrzenie: "Participation in the delight of generations is exhilarating in itself. The feeling that this century-old delight may be repeated, that one may agree with it from the depth of one's gaze. But the gaze looks for words to describe itself with great effort. Memory shifts facts, dates, groups associations, confronts interpretations. Attention suggests some reflections, incites to engage in a shy and obstinate squabble with some from among the teachers of our emotions" (p. 7).

32 D. Lisak-Gębala, 'Rozmyślające widzenie'. Projekt eseistyczny Joanny Pollakówny, [in:] Strony Joanny Pollakównny, eds. A. Kozłowska, J. Zieliński, Warszawa 2016, p. 255. Lisak-Gębala also formulates the primary stages of Pollakówna's essays in which the reflection moves "from gazing at paintings, through activation of erudition to the stage of formulating her own or universal opinions by Pollakówna" (Ibidem, p. 261). Lisak-Gębala devoted a part of her outstanding book to Pollakówna: Wizualne odskocznie. Wokół współczesnej polskiej eseistyki o malarstwie i fotografii, Kraków 2016.

${ }_{33}$ D. Lisak-Gębala, 'Rozmyślające widzenie'..., p. 259. 
about mortal life. This could signify a direction of the interpretation, which saves the painter from the suspicion of tragic doubt: "Sudden vision of the human world, a sensation - through a wink-long sharp vision - of existence in its loneliness, cruelty and, at the same time, acute human closeness is one thread", the poet writes on Józef Czapski's painting, "But there is still (...) another one, extremely important (...) - there is the transparent silence of a held breath in it" (p. 271). "Death, that last act of life not taking the matters of life into consideration, has nothing to do with the act of creation which always carries the measure of the future and manifesting itself as an act of hope in this sense" (p. 119).

In Pollakówna's essays, the attention of critics is drawn not only to the specific duality of the discourse (matters of art and matters of life), but also the very method of approaching the discussed paintings: their poetic making-present which is far away from abruptness and abstractness of scientific terms. As Jan Zieliński notices, “One specialty of Joanna Pollakówna's writing on art is ekphrasis, verbal descriptions of paintings. They are distilled from the course of the narration with sudden condensation, build-up of rare but not necessarily scholarly words, transition to a different register, full of poetry but at the same time concrete" ${ }^{\prime \prime 4}$. Jacek Sempoliński, probably the first one to appreciate the uniqueness of the essayistic diction of the author of Glina i światto, writes that:

There really are few books on art in the Polish literature which are not as much dissertations or collections of reviews as a presentation of a free thought subject only to the willingness to get closer to the phenomenon of the work. (...) A historian of art is not so much a person who got to know, read, saw a lot of things, as someone who developed a certain disciplined mental control, noticed regularities, created an overall own Form, and perceives the world of art through the feeling of this form $(\ldots)^{35}$.

In their letter from 1996, thanking for Pollakówna's radio commentary on the painter's exhibition, Stanisław and Waleria Fijałkowski admit that: “(...) we were captivated by the precise discourse of an analyst with all the features of real poetry which opens specialist terms to the spiritual dimension, how real and spiritual at the same time the matter of the creative process is" ${ }^{\prime \prime 3}$.

Sometimes, however, the very features of Pollakówna's essayistic writing which determine the uniqueness of her sketches become reasons for not understanding them. The precision of poetic metaphor, the uniqueness of the feeling of art - appreciated by Sempoliński as well as Stanisław and Waleria Fijałkowski - are elements sometimes received as negligence of the scientific workshop. Zieliński notices that:

\footnotetext{
${ }^{34}$ J. Zieliński, Wymiary aniołów, "Zeszyty Literackie" 2003, no. 3, p. 232.

35 J. Sempoliński, Władztwo i służba, "Twórczość" 1994, no. 9, p. 122.

36 A letter from Waleria and Stanisław Fijałkowski to Joanna Pollakówa - 12 January, 1996 - Adam Mickiewicz Museum of Literature in Warsaw.
} 
She was a historian of art and she was a poet. These two domains intertwined so ideally that some readers of Joanna Pollakówna's books on art were reserved about ekphrases included in them, descriptions of concrete paintings written in language full of poetry. As if they did not want to believe in the possibility of achieving scientific precision with the use of words which are not commonplace and sometimes even words which are used only once having been coined to convey the shade of a colour or the way in which a lump of pigment exists ${ }^{37}$.

The correspondence of the poet with publishing houses and editorial boards reveals numerous signals of mutual misunderstandings. The letter written in 1989 by Barbara Torunczyk, the editor-in-chief of Zeszyty Literackie, to which Pollakówna proposed a draft on paintings by Stanisław Rodziński, does include a clear suggestion that the text should not be published, although it was written in a cordial tone. Reservations refer to some extent to the works of the artist who the editor describes as: "halfway «Grottger» halfway "Matejko» of the epoch of the Pope and Solidarity, which is of little appeal" ${ }^{38}$. There are, however, more comments like that one:

Admittedly, it seems to me that your draft, precisely due to its high tones and character of iconography, is more in tune with the sensitivity of the Polish reader. Here, I am afraid, these two central notes sound dull and unconvincing, even for me. I would not like to go too far in disseminating this tonality. It prevails in the country and that is probably enough (...). To be frank, if our decision is positive, it is because of you. Both R.'s painting as well as his direction and all high tones, despite all my respect and recognition, and even some sentimental inclination towards sharing similar moods, are for me something that belongs to the opposite direction with regard to what we have chosen. I would even say that the journal exists so that 'other tones' may be heard. I am afraid that the most vivid features of your draft will not resonate as you have assumed (precisely because the factor of empathy completely ceases to work) and the whole rest, instead of showing R.'s painting, shows the local public its typicality being part of today's Polish sensitivity ${ }^{39}$.

It seems that the draft does not correspond with the new aesthetic postulates and it fails to realise "other tones". In 1989, the need to break from the national and historical narrative becomes a priority and it gives rise to suspicion with regard to texts which resonate the excessively familiar, romantic note $^{40}$. Hence Pollakówna's essay is assessed (maybe more strictly than it

37 J. Zieliński, Wnętrze skorupki, “Tygodnik Powszechny” 2002, no. 27, p. 10.

38 A letter from Barbara Toruńczyk to Joanna Pollakówna - 13 July, 1989 - Adam Mickiewicz Museum of Literature in Warsaw.

39 Ibid.

40 This phenomenon attracted the attention of, for instance, Przemysław Czapliński and Piotr Śliwiński: "About the year 1986, both in prose and in poetry there was an increase in phenomena showing some exhaustion of the formula of engaged literature and growing willingness of writers (...) to speak in other languages than those which dominated the range of 
deserves?) as hermetic, and even evoking associations with the hackneyed, excessively pompous Polish folklore.

Torunczyk points to "the high tone" of the draft. Although it is difficult to refer to Pollakówna's texts on painting as lofty or solemn, one really can hear in them seriousness necessary in these places where art meets with life and where, contrary to new aesthetics, beauty preserves its solemnity. The reader of Weneckie tęsknoty or Glina i światto understands Torunczyk's comment even if they would not like to agree with her. Or perhaps the tonality of the draft on Rodziński differs from the tonality characteristic of the author that is present in her other texts? This will be difficult to ascertain.

Torunczyk leaves the decision about the publication to Pollakówna. The draft is withdrawn. It is not known if the only text which the poet devotes to Rodziński (published a few years later in Tygodnik Powszechny on the occasion of the painter's exhibition in the Kordegarda Gallery) uses in any way the essay not published in Zeszyty Literackie ${ }^{41}$. It is worth noticing, however, that Pollakówna remains an admirer of paintings of the author of Krajobraz z chmura (A Landscape with a Cloud) and the title of the essay selected by her, Mądrość wzruszenia (The Wisdom of Affection), seems to defend this feature of Rodziński's work which, according to Toruńczyk, evokes this slightly shameful "sentimental disposition" in the recipient.

It is worth noting one more comment of the editor of Zeszyty Literackie: the empathy of readers is a condition which enables to reveal the most vivid features of Pollakówna's essay-writing. It is impossible to talk about understanding without the initial trust to the poet which enables one to share the assumptions that are part of her works. The effects of the lack of empathy can be catastrophic. This can be seen in the rough draft of the letter of the poet to one of editorial boards:

\section{Dear Madam,}

My work on the text dragged beyond measure due to an incredible number of reservations, derisive questions and, in particular, arbitrary far-reaching stylistic and lexical alterations introduced into my manuscript (...). Ms R. was absolutely right, complaining to you about the difficulty in understanding these fragments or other; now, having analyzed, one after another, all her comments/ironic exclamation marks signalled on 240 pages etc., I have no doubt that she just understands neither this book nor this type of essay writing. Well, we were both unlucky: she was struggling with a text so foreign to her and I was trying to save this manuscript, not so

patriotic and civil discourses in the first part of the decade. Or maybe this way: there was still no answer to the question «how in a different way», but the awareness that «it is no longer possible this way» continued to persist". Cf. P. Czapliński, P. Śliwiński, Literatura polska 19761998. Przewodnik po prozie i poezji, Kraków 1999, p. 169.

${ }^{41}$ Cf. J. Pollakówna, Mądrość wzruszenia. O pejzażach Stanisława Rodzińskiego, "Tygodnik Powszechny" 1995, no. 2, p. 13. 
much edited as remade, with important sentences or even paragraphs being crossed out $(. . .)^{42}$.

What may the "derisive questions" of the editor refer to? Perhaps she is annoyed by one-time words indicated by Zieliński, perhaps "ironic exclamation marks" appear next to newly invented lexemes or formula defining hues, such as "ethereal and misty shades of blue", "the white broken by greyish half-turned yellow"? Perhaps some metaphors, poetic inversions, illogical convolutions of visual, auditory, and taste sensations seem incomprehensible? What is closed with a full stop, known because it was repeated, does not cause reservations. Pollakówna's originality requires the reader's agreement to follow the brand new, to yield to poetry: precisely to treat this poetry as seriously as possible.

Pollakówna's reaction to a lack of understanding was withdrawal (this is the case with the draft on Rodziński). The author does not change her own perspective, does not yield to external pressure. She is capable of defending her "different point of view" efficiently and sarcastically. Her decisive tone reveals the certainty of the feeling and the certainty of the shape of the words. However, prior considerations indicate that this certainty conceals the awareness of not being conclusive. For Pollakówna, the defence of the seeing imagination is the defence of purblind imagination: of the thought reaching so far as to suggest its continuation which is unknown to the poet. The draft on Artur Nacht-Samborski finishes in this way, with the opening to the mystery:

And so this wonderful painting slowly reveals itself to us in its completed, precise whole: with its specific delicate yet strong architecture of the picture, with condensed imagination, closed in a poetic hieroglyph concealing lyrism, humour, sense of idiosyncrasy and some primordial yet universal content. (...). A long sequence of pictures moving in front of us offers us its sign to be read on and on, deeper and deeper, its signal sent by the face-mask, a hieroglyph of palm leaves against the cobalt background, a supple vegetal skeleton among rectangles of boldly balanced colour. An articulate voice not adding anything, speaking through the thicket of strange beauty of the painting matter. (p. 338)

Pollakówna's interpretations, detailed and in-depth, emphatic and tender, reveal the longing for "a clear, ecstatic vision" and focus on the material detail which fosters imagination. They are persistent in looking for a human being in order to find a work of art. In this search, they remain reliable and "seeing", ready to shift from the copious, in-depth comment to

${ }^{42}$ A rough draft of Joanna Pollakówna's letter from 16 October, 1999, Adam Mickiewicz Museum of Literature in Warsaw. The original spelling from Pollakówna's manuscripts is preserved in all the quotations. The name of the publishing house and the editor are omitted. Giving the reasons for the misunderstanding, R. Pollakówna formulates an important definition in the correspondence with the editor: "So I stress again once this misunderstanding has taken place: the book Glina $i$ światto is a collection of essays, a sum of thoughts accumulated in the space of a few years on the subject of art and issues of human life seen through painting (...)". 
one condensed feeling thought. They explain and illuminate. In the field of spiritual experience, their point of departure remains, however, not far from the point of destination. The question-illumination about "How to rise to texts?" - opening each text of the poet - is answered, like an echo, in a way dictated by the greatness of imagination feeling that there is something more, something further: "How to rise to texts?"

\section{REFERENCES}

Arno A., Gęstość stowa, "Zeszyty Literackie" 2014, no. 4.

Błoński J., Widzieć jasno w zachwyceniu: szkic literacki o twórczości Prousta, Warszawa 1965.

Didi-Huberman G., Przed obrazem. Pytanie o cele historii sztuki, transl. B. Brzezicka, Gdańsk 2011.

Dokumenty Joanny Pollakówny i jej dotyczace, Adam Mickiewicz Museum of Literature in Warsaw, ref. no. 5726.

Drzewucki J., O tym, co widzialne i co niewidzialne, "Rzeczpospolita" 2003, no. 155.

Eco U., Autor jako hipoteza interpretacyjna, [in:] Lector in fabula. Wspótdziałanie w interpretacji tekstów narracyjnych, transl. P. Salwa, Warszawa 1994, pp. 90-96.

Górecka E., Między znakami: słowo i obraz w poezji Joanny Pollakówny, "Świat i Słowo. Filologia - nauki społeczne - filozofia - teologia" 2010, no. 2.

Korespondencja Joanny Pollakówny, vols. 1-5, Adam Mickiewicz Museum of Literature in Warsaw, ref. no. 4871, 5060, 5725.

Kozak P., Estetyka A. G. Baumgartena jako pietystyczna lektura filozofii C. Wolffa - draft, https://www.academia.edu/10784122/Estetyka_A.G.Baumgartena_jako_pietystyczna_lektura_filozofii_C.Wolffa, [accessed 10.08.2019].

Lisak-Gębala D., Wizualne odskocznie. Wokół wspótczesnej polskiej eseistyki o malarstwie i fotografii, Kraków 2016.

Pollakówna J., Glina i światło, Wrocław 1999.

Pollakówna J., Mądrość wzruszenia. O pejzażach Stanisława Rodzińskiego, "Tygodnik Powszechny" 1995, no. 2.

Pollakówna J., Myśląc o obrazach, Warszawa 1994.

Pollakówna J., Weneckie tęsknoty. O malarstwie i malarzach renesansu, Warszawa 2002.

Pollakówna J., Zapatrzenie. Myślac o obrazach, myślac o malarzach, Gdańsk 2012.

Proust M., Du côté de chez Swann, Paryż 1946.

Sempoliński J., Władztwo i stużba, "Twórczość" 1994, no. 9.

Strony Joanny Pollakówny, eds. A. Kozłowska, J. Zieliński, Warszawa 2016.

Teresa of Ávila, Księga życia, transl. H. Kossowski, Kraków 2014, p. 269.

Trzeciak P., Barwy Wenecji, "Nowe Książki” 2003, no. 7/8.

Zaleski M., Stowo zapomniane?, [in:] Dwutygodnik.com. Strona kultury, https://www. dwutygodnik.com/artykul/360-slowo-zapomniane.html, [accessed 1.08.2019].

Zieliński J., Wnętrze skorupki, “Tygodnik Powszechny" 2002, no. 27.

Zieliński J., Wymiary aniołów, “Zeszyty Literackie" 2003, no. 3. 


\section{SUMMARY}

The paper focuses on the essayistic output of Joanna Pollakówna, a poet and a historian of art, an author of several books of sketches devoted to European painting. It draws attention to the necessity of reading her poetry and essays - which are inseparable and illuminate one another - in a parallel way.

The first part of the article analyses the way of treating art typical of Pollakówna: the experience of reception which reveals the following of the illumination, the awareness of significance, and mystery. The paper shows that the poet's strategy towards the mystery of beauty consists in launching the empathic imagination capable of capturing the fleeting experience which seems to escape. The response to painting - which goes beyond the level of interpretation and chooses 'adding' rather than cataloguing meanings - is treated, after Didi-Huberman, as "capturing through the visible", which leads to "producing and transforming".

The second part of the article is devoted to selected essays which manifest the transition from the intuition of mystery to the in-depth and creative answer of imagination: imagination following not only the work of art, but also the artist, the interesting relationship between them. References are made, for instance, to the private archive of the poet and her notes from art galleries.

The reception of Pollakówna's work is discussed in the conclusion of the paper. Quoting the voices of critics and the private correspondence of the poet with editors (which remains unpublished), one may argue that the essayistic method of the poet has been both acclaimed and not comprehended.

\section{Keywords}

Joanna Pollakówna, Zapatrzenie, Myśląc o obrazach, Weneckie tęsknoty, Glina i światto

\footnotetext{
Agata Szulc-Woźniak - a doctoral student in the Faculty of Polish and Classical Philology at Adam Mickiewicz University in Poznan. Her research interests include the 20th-century Polish poetry. She is preparing her Ph.D. dissertation on Joanna Pollakówna. She has published in e.g. "Ruch Literacki" and "Konteksty Kultury".

e-mail: agata_szulc@onet.pl
} 